\title{
Confidence and financial crisis in a post-Keynesian stock flow consistent model
}

\author{
Edwin Le Heron*
}

\begin{abstract}
The paper aims at showing that one of the main channels by which the US 2007 financial crisis became a real and global economic crisis is the sonfidence channel, i.e. that the financial crisis affected firms, banks and households' expectations and confidence, thus leading to what they were fearing. And I propose to model expectations and the state of confidence of private agents to use the indexes calculated by national statistical services from monthly polls.

JEL classifications: $E_{I 2}, E_{27}, E_{41}, E_{43}, E_{47}, E_{5 I}, E_{52}$

Keywords: confidence, financial crisis, stock-flow-consistent modelling
\end{abstract}

\section{Introduction}

While it was only a US subprime mortgage crisis in 2007, economic growth and employment are now deteriorating sharply all around the world. Our goal is to understand how this financial crisis in the US has become a global real economic crisis, especially in Europe and in a country like France. Many transmission channels can be considered and have certainly had an influence. Keynes's thought gives us an answer, but this answer raises a very difficult question. With the principle of effective demand, Keynes stressed the importance of psychological variables in determining economic growth, particularly because of radical uncertainty. Expectations are often self-fulfilling. But how can we model this brilliant insight? That is much more complex than adaptive or rational expectations. Many post-Keynesians claim that it is impossible to model within the framework of radical uncertainty. As noted by Davidson (2007: 62):

* Sciences Po Bordeaux, SPIRIT, France. My grateful thanks go to anonymous referees, Emmanuel Carré, Jérôme Creel, Wynne Godley ${ }^{\dagger}$, Mark Lavoie, Jacques Mazier, Tarik Mouakil, Dominique Plihon, Malcolm Sawyer, Eric Tymoigne and Gennaro Zezza for their helpful comments on the previous drafts.

Correspondence Address:

Edwin Le Heron, Sciences Po Bordeaux, Centre Emile Durkheim, CNRS UMR 5116, Pessac, F-33607, France, e-mail: e.le.heron@sciencespobordeaux.fr.

Received 7 June 20I0, accepted I8 December 2010

(C) INTERVENTION 8 (2), 20II, 36I-387 
"In Keynes's approach, as opposed to the classical theory and the sscientific approach of professor Samuelson, people recognize that their economic future is uncertain (nonergodic) and cannot be reliably predicted from existing market information."

Unfortunately the statistical methods used today are building the future from the past (ergodic approach). The paper aims at showing that one of the main channels by which the US 2007 financial crisis became a real and global economic crisis is the sconfidence channel, i.e. that the financial crisis affected firms, banks and households' expectations and confidence, thus leading to what they were fearing. And I propose to model expectations and the state of confidence of private agents using the indexes calculated by national statistical services from monthly polls. These show in real time what the state of confidence in an economy is. These data are really forward looking.

First, I shall study the link between a local financial crisis and a global real crisis to understand the sconfidence channel. Second, I shall build a post-Keynesian stock-flow consistent (SFC) model (Lavoie/Godley 200I and 2007, Dos Santos/Zezza 2004, Mouakil 2006, Le Heron/Mouakil 2008, Le Heron 2009) with a complete private banks sector. I shall introduce the state of confidence of the private sectors. Third, I shall simulate the model to study the effects of the current financial crisis that involves a confidence crisis. The aim is to analyse the channel of transmission to the real world of changes in the state of confidence of private sectors. I shall explore the confidence channel with a modelling based on French indexes of state of confidence (firms, banks and households) from 2005 to the end of 2009.

\section{From the US financial crisis to the European real crisis}

Our goal is to understand how the US financial crisis has become a global real economic crisis, especially in Europe. Many transmission channels can be considered. For some European countries, the explanation may be found fairly easily. Banks and financial activities were an important part of the GDP of Great Britain and Iceland and were very globalised. More generally, distressed assets have contaminated banks around the world. Speculative bubbles in the housing market grew in Spain, Ireland or London. Irish growth relied heavily on direct investment by US companies and thus the Irish business cycle was linked to the US business cycle. The building sector was over 26 percent of Spanish GDP. The British pound has depreciated greatly since 2007. Greece was experiencing structural problems, especially of governance that could only be amplified by the financial crisis.

However, a large part of Continental Europe had no specific reasons to suffer its deepest depression since World War II. In much of Europe, there was no bubble in housing markets; banks were moderately engaged in the US speculative markets and their profitability remained strong. Households were unlikely to suffer a negative wealth effect, since their incomes or pensions were not linked to stock markets. Household debt was low when compared to the situation of the United States. Certainly European entrepreneurs are living in a globalised world, but the US market is not an important outlet for European trade. Moreover, the US 
crisis involved a great moderation in prices of raw materials, and particularly a strong and quick drop in the price of oil. It was good news for production, and Europe could expect lower inflation and lower interest rates. The euro has allowed sixteen European countries to maintain stability of exchange rates with their key economic partners. Germany, for example, exports to many emerging countries which have not experienced a major crisis and where high rates of growth were starting to rebound quickly. Finally no restrictive fiscal policy was conducted during the period 2005-2009. Instead, after the outbreak of the crisis, budget expenditures have been substituted for the weakness of private initiative, with the danger of a sovereign debt crisis, but only after 2009 .

My hypothesis is that the most important channel of transmission of the US financial crisis is confidence. Of course, I do not say it is the only one. But I am particularly interested in psychological variables such as the state of confidence, because these variables play a key role in the post-Keynesian framework. With radical uncertainty, agents' expectations can become self-fulfilling prophecies. As Keynes suggested, in economics, when the people go out with umbrellas, it rains. Group expectations are the strongest predictor of future events and the most important expectations are those of entrepreneurs. In the General Theory, Keynes stressed the importance of psychological variables in determining economic growth, particularly because of radical uncertainty. The state of confidence of private agents affects the economy through three psychological laws, which are at the heart of my post-Keynesian model:

- for entrepreneurs: it is the marginal efficiency of capital that determines reffective demand and therefore production, income and demand of external finance;

- for households: it is the marginal propensity to consume that determines consumption;

- for commercial banks: it is the liquidity preference that determines reffective financer. Indeed, as in our previous works (Le Heron 2007a), we generalise liquidity preference to commercial banks.

A loss of confidence, which corresponds to a generalised increase in liquidity preference, that is to say the fear of long-term commitments, leads quickly to an economic crisis. Entrepreneurs want to stop to invest, households to consume, banks to lend. With the collapse of effective demand, household incomes will decline, resulting de facto in a decrease of consumption. As shown by Minsky (1975), the crisis is the deeper as prosperity has previously led to a sharp increasing risk (bubble).

As Keynes clearly defined in the General Theory (ch. I2, I973 [I936]: I47-I48):

"The considerations upon which expectations of prospective yields are based are partly existing facts which we can assume to be known more or less for certain, and partly future events which can only be forecasted with more or less confidence. [...] We may sum up the state of psychological expectation, which covers the latter as being the state of long-term expectations; [...]. The state of long-term expectation, upon which our decisions are based, does not solely depend, therefore, on the most probable forecast 
we can make. It also depends on the confidence with which we make this forecast on how we rate the likelihood of our best forecast turning out quite wrong. [...] The state of confidence, as they term it, is a matter to which practical men always pay the closest and most anxious attention. But economists have not analysed it carefully and have been content, as a rule, to discuss it in general terms. In particular it has not been made clear that its relevance to economic problems comes in through its important influence on the schedule of the marginal efficiency of capital."

The vision of the future by entrepreneurs largely determines the present and therefore what will be really our future, but also the confidence that entrepreneurs have in this vision. Thus Keynes demonstrates the simultaneous importance, and partial contradiction, of animal spirits (spontaneous risk taking) and conventions (confidence in the stability of the present). The crisis is reflected in lower animal spirits and the questioning of conventions. This higher uncertainty increases preference for liquidity, the curse of capitalism.

"We are merely reminding ourselves that human decisions affecting the future, whether personal or political or economic, cannot depend on strict mathematical expectations, since the basis for making such calculations does not exist; and that it is our innate urge to activity which makes the wheels go round, our rational selves choosing between the alternatives as best we are able, calculating when we can, but often falling back for our motive on whim or sentiment or chance." (Keynes 1973 [I936]: I62-I63)

"The essence of this convention - though it does not, of course, work out quite so simply - lies in assuming that the existing state of affairs will continue indefinitely, except in so far we have specific reasons to expect a change." (Keynes 1973 [1936]: 152)

Now I shall build the SFC model by including the state of confidence of private economic agents and conventions. The monthly polls of the state of confidence will be the chosen as the way to understanding the spread of the US financial crisis to European GDP.

\section{The post-Keynesian Stock-Flow Consistent growth model}

I summarise only the most specific features of the model ${ }^{\mathrm{I}}$ with five sectors: government, firms, households, private banks and central bank. SFC modelling is based on two tables: the transactions matrix (flows, appendix 3 ) and the balance sheet matrix (stocks, appendix 4). The complete model (appendix 2) contains 63 equations.

All production must be financed. However, current production is financed by the working capital of entrepreneurs (retained earnings) and by contracted revolving funds granted by banks at the current rate of interest. These two factors constitute a shock absorber

I You will find more explanations in Le Heron and Mouakil (2008) and Le Heron (2009) for the post-Keynesian model and in Le Heron (2008) for the Keynesian stock-flow consistent model. 
to possible monetary rationing by banks. I am essentially limiting my study to the effects that a fall in the state of confidence of banks, firms and households might have on new financing for investment and growth of production. Let us proceed to examine the gross supply $(\varphi)$ and the net supply $(\Delta F)$ of finance by banks - that is to say, the new flow of money, as opposed to the existing stock of money $(D)$. Also, there is a stock of money demand equal to transaction, precaution, finance and speculative motives, whereas the desired gross finance demand $\left(\varphi^{d}\right)$ represents the new flow of financing required by firms $\left(I^{d}\right)$ plus the redemption of the debt (amortisation = amort) minus the undistributed profits $\left(P^{u}\right)$. Thus the internal funds of firms $(I F)$ represent the undistributed profits $\left(P^{u}\right)$ minus the redemption of the debt (amort). Assuming a closed economy, demand for money can be satisfied by banks, either by the stock markets or by credit. At the end of the period, net financing demand $\left(\Delta F_{D}\right)$ can be constrained by net money supply from banks $(\Delta F) . \Delta F$ determines monetary creation in the period.

The national income $(Y)$ adds the household consumption $(C)$, investment of the firms $(I)$ and the public expenditure $(G)$. The rate of growth of the national income is $g r_{y}$.

\section{Fiscal policy of the government}

Government expenditures are only on final sales of consumption goods. The government only collects taxes from households on wages. The government finances any deficit issuing bills, so that the supply of treasury bills $(B)$ in the economy is identical to the stock of government debt. In other words, it is given by the pre-existing stock of debt plus its current deficit $(D G)$. The current deficit of the Government includes the redemption of the national debt. I assume that private banks give limitless credit to government at the long-term rate of interest $\left(i_{l}\right)$.

To analyse the consequences of a supply shock, I assume a stabilising effect of fiscal policy. Public expenditure $(G)$ is always growing at the same rate $\left(g r_{y}\right)$ as the national income $(Y)$ with a lag of one year. Tax revenue is proportional to income and hence varies in line with the public expenditure. With the government debt, the global impact is linked to the key interest rate and, then, to monetary policy. It looks like a co-ordination between the monetary and the fiscal policies. The final effect of fiscal policy is measured by the government deficit $(D G)$. Our economy has a self-stabilising tendency due to the fiscal policy.

$$
\begin{aligned}
& G=G_{-1}\left(1+g r_{y-1}\right), \\
& D G=G+\left(i_{b-1} B_{-1}\right)-T-P_{c b} .
\end{aligned}
$$

\section{Investment of firms}

The investment function is the most important one in a growth model. The stock of capital $(K)$ increases with the flow of net investment $(I)$ that is financed by total internal funds of firms and by external funds from commercial banks (gross finance $=\varphi$ ). Firms prefer selffinancing (Eichner 1976), because borrower's risk is associated with external funds. Selffinancing of firms corresponds to retained earnings $\left(P^{u}\right)$ minus redemption of debts of firms 
(amort). Firms issue equities $(E)$, bonds with fixed rates of interest $(o f)$ and commercial papers $(C P)$, and borrow money from banks (at a variable rate) $(L)$ to finance investments. Amortisation only concerns debt: loans, bonds and commercial papers.

$$
\begin{aligned}
& I \equiv \varphi+I F, \\
& I F=P^{u} \text {-amort }, \\
& \text { amort }=\left(a_{l} L_{-1}\right)+\left(a_{o f} o f_{-1}\right)+\left(a_{C P} C P_{-1}\right) .
\end{aligned}
$$

In this model, I differentiate between effective investment $(I)$ and desired investment of firms $\left(I_{D}\right)$. The banks finance the latter totally or in part according their lender's risk $(L R)$ (see equations $15,16,18)$. Rationing in investment financing can exist $\left(\varphi<\varphi^{d}\right.$ or $\left.I<I_{D}\right)$. The desired rate of accumulation $\left(g r_{k D}\right)$ is a function of an exogenous state of confidence $\left(\gamma_{0}\right)$, the capacity utilisation rate $(u)$ and of borrower's risk $(B R)$, which is measured by the rate of cash flow $\left(r_{c f}\right)$ and by the financial condition index $(F C I)$. The rate of cash flow is the ratio of retained earnings to capital, and the financial condition index captures the sensitivity of investment with respect to the level of indebtedness, to the long-term interest rate, to the short-term interest rate, and to the financial capitalisation ratio. The lender's risk and the borrower's risk come from Minsky's analysis (Minsky 1975).

$$
\begin{aligned}
& I_{D}=g r_{k D} K_{-1}, \\
& \varphi^{d}=I^{d}-I F, \\
& g r_{k D}=\gamma_{0}+\left(\gamma_{1} r_{c f-1}\right)+\left(\gamma_{2} u_{-1}\right)-\left(\gamma_{3} F C I_{-1}\right), \text { with } \gamma_{i} \text { constant, }
\end{aligned}
$$

where the rate of capacity utilisation is defined as the ratio of output to full capacity output $\left(Y_{f c}\right)$ :

$$
\begin{aligned}
& r_{c f}=P^{u} / K_{-1}, \\
& u=Y / Y_{f c} .
\end{aligned}
$$

The capital to full capacity ratio $(\sigma)$ is defined as a constant:

$$
\begin{aligned}
& Y_{f c}=K_{-1} \sigma, \quad \text { with } \sigma \text { constant }, \\
& F C I=\left(\mu_{1} i_{l} L / K\right)+\left(\mu_{2} i_{c b} C P / K\right)-\left(\mu_{3} E / Y\right), \quad \text { with } \mu_{i} \text { constant . }
\end{aligned}
$$

I measure the output gap $\left(Y_{f c}-Y\right)$ in ratio, with $Y_{f c}$ the output of full capacity. I do not use the potential output of the New Keynesian analysis, that is to say a long term equilibrium respecting the NAIRU. The output of full capacity corresponds to the full employment. Distributed dividends $\left(P^{d}\right)$ are a fraction of profits realised in the previous period:

$$
P^{d}=\left(1-s_{f}\right) P_{-1}, \quad \text { with } s_{f} \text { constant . }
$$




\section{Consumption of households}

I assume that households determine their consumption expenditure $(C)$ on the basis of their expected disposable income and their wealth from the previous period that consist entirely of bank deposits. Following the Kaleckian tradition, wages are mostly consumed while financial income is largely devoted to saving. The consumption decision depends on the state of confidence of households and determines the amount that they will save out of their disposable income. The financial behaviour of households is simplified and they hold only a banking deposit account.

I assume that the state of confidence of households $\left(\gamma_{6}\right)$ influences only the workers, i.e. their propensity to consume $\left(\alpha_{1}=\alpha_{1}^{\prime} \gamma_{6}\right)$. The consumption decision determines the amount $(\Delta D)$ that households will save out of their disposable income $\left(Y_{h}\right)$.

$$
C=\left(\alpha_{1}^{\prime} \gamma_{6} Y_{w}^{a}\right)+\left(\alpha_{2} Y_{v}^{a}\right)+\left(\alpha_{3}^{\prime} D_{-1}\right), \quad \text { with } \alpha_{i} \text { constant } .
$$

\section{Financing by private banks}

Banks do not make loans to households, but financing firms is fundamental in a monetary economy of production. Firms begin by being self-financed and then turn to external finance $\left(\Delta F_{D}\right)$. Banks only finance projects they consider profitable, but confidence in their judgment is variable and can justify various strategies. Banks examine firms' productive and financial expectations and also their financial structure. This investigation is made according to their confidence in the state of long-term expectations of yields on capital assets, influencing what Keynes referred to as ranimal spirits` (Keynes 1936: 16I). The state of confidence of banks is notably taken into account by an exogenous variable $\left(\gamma_{4}\right)$. After the study of expected production and of demand for financing that integrates the firm's borrowing risk, bankers can refuse to finance. The state of confidence of banks summarises these factors.

Banks experience a lender's risk $(L R)$ when underwriting finance and creating money. Lender's risk is the sum of three fundamental risks: risk of default, risk of liquidity and market risk. Market risk can be split into other risks. Fluctuations in capital asset prices modify their value and explain capital risk - which is very high for equities and fixed-yield bonds. For the fixed-yield bonds, capital risk is inversely proportional to interest rates. The risk of income mainly concerns the highly uncertain dividends of equities and the variable yield of loans. Finally, monetary policy involves a money market risk when fluctuations in the money interest rates occur.

In equations $15,18,21,22$, the risks of default and of liquidity are taken into account by the gap of the leverage ratio with a conventional leverage ratio. We also introduce the value of the securities lodged as collateral and the cost of indebtedness for the risk of default. The market risk is taken into account by the expected capital gains on equities $\left(C G_{e}^{a}\right)$ and on fixed-yield bonds $\left(C G_{o f}^{a}\right)$, but also with the central bank interest rate.

When the lender's risk is maximum $(L R=1)$, commercial banks refuse to finance the net investment of firms $(\Delta F=0)$ and desired investment $\left(I_{D}\right)$ faces a serious finance rationing. The flow of net investment is only financed by self-funding, that is retained earnings $\left(P^{u}\right)$, 
minus amortisation of debt, minus capital losses of firms $(C G)$. Thus the money supply (in stock) can be reduced with redemption of debt. If lender's risk is zero $(L R=0)$, desired investment is fully financed $\left(\Delta F=\Delta F_{D}\right.$ or $\left.\varphi=\varphi^{d}\right)$. This is the horizontalist $<$ case. The capital losses of firms are also the capital gains of banks, measured by the capital losses on equities $\left(C G_{e}\right)$ and on fixed rate bonds $\left(C G_{o f}\right)$.

$$
\begin{aligned}
& \varphi=\varphi^{d}(1-L R), \quad \text { with } 0 \leq L R \leq 1, \\
& \Delta F=\varphi-\text { amort }+C G . \\
& C G=C G_{e}+C G_{o f} .
\end{aligned}
$$

Let us examine the bank-balance-sheet channel. Four channels are usually taken into account in the literature: wealth effect (Davis/Palumbo 200I), Tobin's $q$ (Tobin 1969), the financial accelerator (Bernanke et al. 1999) and the capital of banks (Van den Heuvel 2002). I had these four channels in my previous model (Le Heron 2009). In this model, I put the value of collaterals in place of the Tobin's $q$.

In the model, the lender's risk $(L R)$ is measured by the difference between the current leverage ratio and the conventional leverage ratio (quantity of indebtedness), by the variation in the value of the securities lodged as collateral $\left(V_{C}\right)$ and by the cost of indebtedness $\left(i_{c b}\right)$. The higher the current indebtedness of firms $((C P+O F+L) / K)$ compared to accepted indebtedness, the greater the lender's risk. The accepted indebtedness is conventional, but this conventional indebtedness can increase during a boom and decrease during a crisis. The variation in the value of the securities lodged as collateral $\left(V_{C}\right)$ is measured by the value of equities $(E)$ against the value of equities of the last period. The financial value is the value of the equities on the market.

$$
\begin{aligned}
& L R=-\gamma_{4}+a_{1}\left(l e v_{-1}-l e v_{c}\right)-b_{1} V_{C}+c_{1} i_{c b}, \text { with } \gamma_{4}, a_{1}, b_{1}, c_{1} \text { and } l e v_{c} \text { constant } \\
& l e v=(C P+O F+L) / K \\
& V_{C}=E / E_{-1} .
\end{aligned}
$$

I follow the methodology developed by Godley and Lavoie (2007) and inspired by Tobin (I958) to define the portfolio behaviour of banks. Banks can hold four different assets: bonds (with fixed rate of interest) $O F=o f p_{o f}$; equities $E=e p_{e}$; loans at variable long-term interest rate $(L)$; and commercial paper $(C P)$ at short-term interest rate.

Monetary authorities determine endogenously the key rate on the money market $\left(i_{c b}\right)$ following the Taylor rule. While central banks fix the short-term rates, private banks' liquidity preference determines banking rates (short-, medium- and long-term interest rates). Significant rates for growth and financing (loans) are the long-term interest rates $\left(i_{l}\right)$. The link between short-term and long-term interest rates is complex. Macroeconomic banking interest rates $\left(i_{l}\right)$ are the production costs of money plus a risk premium. The first element corresponds to functioning costs (wages, investment, properties), payments for monetary 
liabilities (subject to the banks competition for households savings) and the cost of highpowered money determined by the central bank, and to a rate of margin $(\chi)$ corresponding to standard profits of banks. The production costs of money are equal to $\left(i_{c b}\right)$ plus a relatively constant mark up $(\chi)$.

Risk premiums are not constant because they are the fruits of the banks' liquidity preference, which covers lender's risk $(l r)$. Five expectations strongly influence risk premiums: expectations about productivity, economic evolution and budget; expected inflation; the level of future short-term rates of interest; financial markets' evolution and capital assets prices; foreign long-term rates. In the model, I use the same lender's risk as the one seen previously (equation $\mathrm{I} 8$ ), that is a mix of the state of confidence, leverage ratio and variation in the value of the securities lodged as collateral. But with the different coefficients $\gamma_{5}, a_{2}$ and $b_{2}, l r$ can be negative and reduce the mark up. Therefore the long-term interest rate becomes endogenous and the spread between $i_{c b}$ and $i_{l}$ is not constant. Contrary to the horizontalist view, I introduce an endogenous curve of the interest rates. To explain the short-term interest rates $\left(i_{b}\right.$ or $\left.i_{c p}\right), i_{c b}$ and $\chi$ are sufficient. On the contrary, $l r$ is the primary variable in order to explain long-term interest rates $\left(i_{l}, i_{o f}\right)$. Banks apply a spread $\left(\chi_{3}\right)$ between the key rate and the rate on deposits in order to realise profit.

$$
\begin{aligned}
& i_{l}=i_{c b}+l r+\chi_{1}, \quad \text { with } \chi_{1} \text { constant and } \chi_{1}>\chi_{2}, \\
& l r=-\gamma_{5}+a_{2}\left(l e v_{-1}-l e v_{c}\right)-\left(b_{2} V_{C}\right)
\end{aligned}
$$

with $\gamma_{5}, a_{2}, b_{2}, l e v_{c}$ constant and $c$ representing the convention on the 'normal debt ratio.

$$
\begin{aligned}
& i_{c p}=i_{c b}+\chi_{2}, \quad \text { with } \chi_{2} \text { constant and } \chi_{1}>\chi_{2}, \\
& i_{d}=i_{c b}-\chi_{3} .
\end{aligned}
$$

The initial structure of interest rates is as follows: $i_{l}>i_{o f}>i_{c p}>i_{b}=i_{c b}>i_{d}$.

Economic activity also depends on the animal spirits of banks. Finance scarcity can only be the consequence of a deliberate choice. 'Desired scarcity of financing is the sign of banks' liquidity preference. From an optimal structure of their balance sheet, I can measure the profits of commercial banks $\left(P_{b}\right)$ obtained by monetary financing:

$$
P_{b} \equiv i_{b-1} B_{-1}+i_{l-1} L_{-1}+i_{c p-1} C P_{-1}+i_{o f} o f_{-1}+P^{d}-i_{d-1} D_{-1}-i_{c b-1} R E F_{-1} .
$$

\section{Monetary policy of central bank}

Following the theory of endogenous money, I assume that the central bank is fully accommodating. Obviously, central banks in Europe (ECB, BoE) are not post-Keynesian (Le Heron 2007b). Therefore, I use a Taylor rule and a kind of New Keynesian Phillips Curve (NKPC) for the modelling of central bank behaviour. First, the central bank fixes the key rate of interest $\left(i_{c b}\right)$ using a Taylor rule, i.e. central bankers react to output gap and inflation gap; and second it provides whatever advances $(R E F)$ demanded by banks at this 
rate. Taylor propounded his first instrument rule in 1993, modelling the dual mandate of the Fed (Taylor 1993). It was founded on the output gap and on the inflation gap. From the Taylor rule, I can derive monetary policy according to three dimensions: strategy, flexibility and intensity. Strategy represents the mandate and therefore the long-term policy. Flexibility measures the deviation in the short term of the policy from the strategy. Intensity is the weight put respectively on output gap and inflation gap. With the `Taylor principle‘, coefficients must be superior to one to avoid that inflation expectations produce inflation (Figure I).

Figure I: Monetary policy of central bank

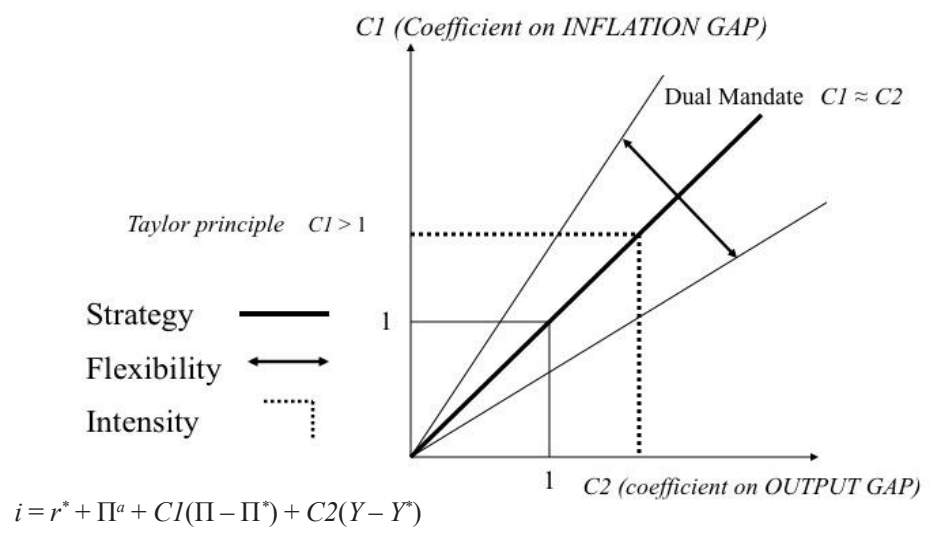

I assume that the central bank uses a flexible Taylor rule. The key interest rate $\left(i_{c b}\right)$ is a negative function of the output gap and a positive function of the inflation gap. The output gap is the difference between full capacity output $\left(Y_{f_{c}}\right)$ and current output $(Y)$. The output gap as a ratio is output over the output gap. I reject the New Keynesian potential output that is founded on a NAIRU. The inflation gap is the difference between current inflation (П) and target inflation ( $\left.\Pi^{*}\right)$. As in the standard Taylor rule, I add a neutral interest rate, exogenously fixed at 2 percent as Keynes (1936) in the General Theory. The inflation target is I percent. At the steady state, the key interest rate is equal to 3 percent, so the real key interest rate is equal to the neutral interest rate $\left(i_{c b}-\Pi^{*}=i^{*}=2\right.$ percent). In this case, the three gaps (output, inflation and interest rate) are equal to zero.

The monetary rule of the central bank is:

$$
i_{c b}=i^{*}+\Pi-\alpha_{4} O G_{R}+\alpha_{6}\left(\Pi-\Pi^{*}\right)
$$

I have some flexibility $\left(\alpha_{4}, \alpha_{6}\right)$ in the instrument function of the central bank. As with the risk management of Alan Greenspan (Le Heron 2006) (balance of risks), the central bank prefers to fight against the greatest danger and focuses on the most important variable in the current period. 


$$
\begin{aligned}
& \alpha_{4}=\alpha_{4(-1)}+\left(a l_{4}\left(O G_{R}-O G_{R(-1)}\right)\right), \text { with } a l_{4} \text { constant. } \\
& \alpha_{6}=\alpha_{6(-1)}+\left(a l_{6}\left(\Pi-\Pi_{(-1)}\right)\right), \text { with } a l_{6} \text { constant. }
\end{aligned}
$$

I am assuming that income distribution is constant, which has been the case in France for the last fifteen years. ${ }^{2}$

$$
W=Y /(1+\rho), \quad \text { with } \rho \text { constant } .
$$

So inflation is not explained by a change in income distribution, but according to the balance of power between entrepreneurs and workers in the labour market. This balance of power is measured by the output gap. As Keynes explained, entrepreneurs set prices after the determination of nominal wages. So they set themselves the real wages and the income distribution. This explains why income distribution may be constant, even with inflation.

If growth of GDP is strong and reduces the output gap, workers may demand higher nominal wages that entrepreneurs transmit without delay to their prices to maintain profit rates (the mark-up is constant). The result is an acceleration of inflation. On the contrary, with the economic crisis and rising unemployment, wages are rising slower than inflation. Inflation is going down as long as entrepreneurs prefer to maintain the same income distribution and lower price increases, trying to sell all their production. A deflationary trend may develop. Inflation and deflation are generated by the productive sector. Except with significant supply and demand shocks, workers demand an increase in their wages that corresponds to the level of inflation in the steady state. Their inflation expectations are anchored on the inflation target of the central bank: the inflation target of the monetary policy thus becomes selffulfilling. So there is a >corridor of stability where inflation expectations are anchored on the target (inflation targeting). Leijonhufvud (I98I: II2n) coined the notion of a >corridor', the idea that for small disturbances the inflation rate is stable while for large disturbances it is unstable. The economy has stability inside the corridor, while it will lose stability outside. Such a `corridor of stability` can provide another way of looking at Keynes's insight (Keynes I936: 249) that the economy is not violently unstable. When inflation is low and close to its target, I consider that the expectations of inflation are anchored on the target. In this case, inflation does not react to the variations of the output gap $\left(O G_{R}\right)$. Inflation depends only on the anticipated inflation $\left(\Pi^{a}\right)$ that is anchored on the target: $\Pi^{a}=\Pi^{*}$. This leads to a horizontal NKPC. But if the variations in output are too important (for instance, close to full capacity output) or, if an exogenous supply shock occurs (for instance, a shock in productivity or in oil price), inflation reacts. Inflation reappears over $O G_{R \operatorname{mini}}$ and disinflation under $O G_{\text {Rmaxi }}$.

To simplify, inflation is only used to determine the reaction of the central bank (monetary policy), and thus the changes in the short-term interest rates. All the values (flows and stocks) are nominal values and there are no fixed prices in the model. But it would

2 The ratios $W / Y$ and $P / Y$ are even the same in 1970 and 2009. Changes in income distribution exist but inside $W / Y$ and $P / Y$. 
be possible to explicitly introduce prices in the set of equations to separate the changes in volume and prices in nominal flows or to introduce the real wealth effects. This is the new consensus in macroeconomics (Taylor rule plus NKPC) and it is therefore suitable for modelling the behaviour of central banks today. The shape of the curve of this special kind of New Keynesian Phillips Curve is shown in the Figure 2.

Figure 2: Inflation curve

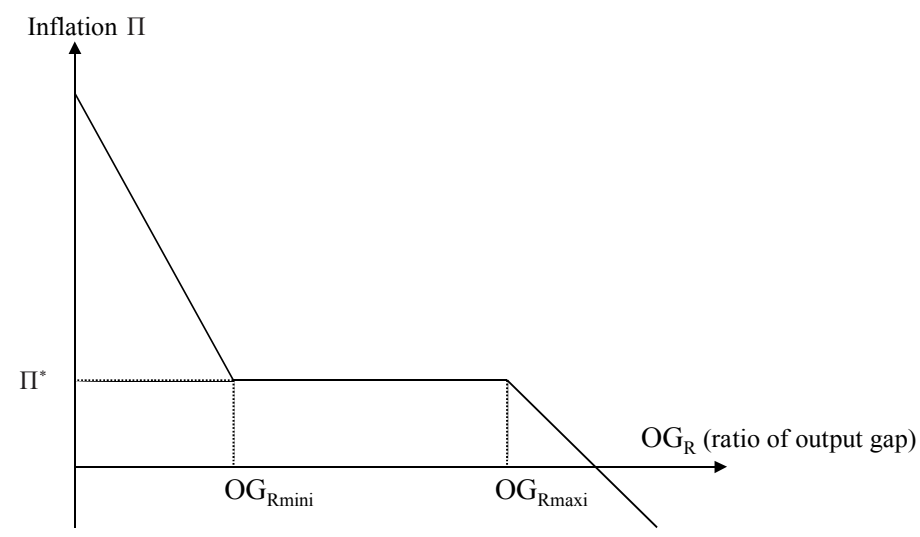

To write the equation of inflation, I use the output gap and the inflation gap:

$$
\Pi=\Pi^{*}+d_{1}\left(O G_{R \operatorname{mini}}-O G_{R}\right)+d_{2}\left(O G_{R \operatorname{maxi}}-O G_{R}\right) .
$$

\section{Experiments about confidence and financial crisis: The case of France}

As we have seen in the first part, many European countries had no specific reasons to suffer their deepest depressions since World War II: no bubble on the housing market, banks moderately engaged in the US speculative markets, no wealth effect for the households, low reliance on the US market, stability of exchange rates with our major economic partners. The sharp fall in oil prices allows lower inflation and lower interest rates. Except for the cases of Great Britain, Ireland, Iceland and Spain, other European countries have experienced the same paradox: They had no reason to suffer from the US financial crisis and yet they have experienced a deep recession. Although our reasoning applies to many European countries, I shall keep the precise French example as the support for my modelling. The rate of growth in France has dramatically fallen to -3.5 percent in the first quarter of 2009 . And the unemployment rate rose from 7.6 percent in May 2008 to Io percent in 2010. 
This model is a mathematical model of a closed modern economy, but it is not fully calibrated on the French economy. Therefore these experiments are only an attempt to simulate the state of confidence with some established figures of confidence index in order to know if we can find the stylised facts of the current period. Our hypothesis is that an important channel of transmission of the US financial crisis to the French growth crisis is confidence. But of course, it is not the only one.

\section{Crisis in the state of confidence}

I make simulations ${ }^{3}$ by imposing changes in the state of confidence corresponding to the period of 2005-2009. To take into account the end of the speculative boom and the current crisis, I experiment with the period from May 2005 (INDEX = IOO) until October 2009. I use the different monthly indicators elaborated by the French National Institute of Statistics and Economic Studies (INSEE). These indexes are calculated from monthly polls on a representative population. I use seasonally adjusted series. Calculated indexes of confidence drive our model and impact on the GDP and the real economy. I do not try to explain these changes in the state of confidence. I assume that these changes impact the real economy and I have no loop from the real economy (GDP for instance) to the state of confidence of the private sectors. Therefore, the state of confidence of the private sectors moves exogenously with the calculated expectations of the private agents. The model is thus completely sorward looking . Radical uncertainty is really taken into account, since only the state of confidence of economic agents explains the deviations from the model's steady state.

Numerous features in our standard model correspond to a 'financialised economy: an important financial market, four different financial assets, the lender's risk, the borrower's risk, a time structure of interest rate. I assume that financial crisis involves essentially a fall in the state of confidence of the economic agents, which then depresses the real economy. The aim is to deal with the channels of transmission of these psychological variables. I want to show that psychological reactions (lower confidence) are sufficient enough to explain the spread of financial crisis to the real sector. I develop four processes for the crisis: changes in the state of confidence of firms, banks, and households and finally in all the private sectors.

Following Keynes, the state of confidence of private agents affects the economy through three psychological laws, which are at the heart of the General Theory: the marginal efficiency of capital for entrepreneurs, the marginal propensity to consume for households and the liquidity preference for banks. Indeed, as in my previous works (Le Heron 2007a), I generalise the preference for liquidity to commercial banks.

Although our economy is closed, taking into account the international dimension of the crisis in polls conducted among private agents justifies our integration of the global dimension of the real world. 


\section{The state of confidence of firms: $F$}

In the post-Keynesian framework, firms' expectations are the most important, because they explain reffective demand. For firms, I use an indicator of the state of confidence of firms $(S C F)$ that summarises more than I8 issues: turning point indicator, recent changes in output, personal production expectations, inventory levels of finished goods, demand and total order books, demand and total export books, personal price expectations, general production expectations, etc. I am taking into account the expectations about international demand too. The changes in the state of confidence of firms $\left(\gamma_{0}\right)$ impact the desired rate of accumulation. It is a good proxy for the marginal efficiency of capital and for effective demand. Pessimistic expectations of firms depress effective demand and involve a supply shock and then a demand shock.

$$
\begin{aligned}
& g r_{k D}=\gamma_{0}+\left(\gamma_{1} r_{c f-1}\right)+\left(\gamma_{2} u_{-1}\right)-\left(\gamma_{3} F C I_{-1}\right), \\
& \gamma_{0}=a_{5} S C F .
\end{aligned}
$$

\section{The state of confidence of households: $H$}

For households, I use the consumer confidence indicator $(C C I)$ to measure their state of confidence $\left(\gamma_{6}\right)$. This summary indicator of confidence analyses five major components derived from monthly polls: the financial situation of households (past and future), the feeling on the general economic situation (past and future) including international perspectives, the major purchase intentions (I2 months). In our model, the consumer confidence indicator influences only the marginal propensity to consume $\left(\alpha_{1}\right)$ out of the expected disposable income of workers $\left(Y_{w}^{a}\right)$. It involves a demand shock.

$$
\begin{aligned}
& C=\left(\alpha_{1}^{\prime} \gamma_{6} Y_{w}^{a}\right)+\left(\alpha_{2} Y_{v}^{a}\right)+\left(\alpha_{3}^{\prime} D_{-1}\right), \\
& \alpha_{1}=\alpha_{1}^{\prime} \gamma_{6} \quad \text { or } \quad \alpha_{1}=\alpha_{1}^{\prime} C C I .
\end{aligned}
$$

\section{The state of confidence of commercial banks: $B$}

For banks, there is not a specific index on the state of confidence of this sector. I use the French business climate index $(B C I)$ that summarises the business tendency surveys of the different economic sectors as banks usually did it. This indicator of French business climate influences the conventional level of the leverage ratio and the lender's risk. The indexes $\gamma_{4}, \gamma_{5}$, $\gamma_{7}$ and $\gamma_{8}$ in the equations of lender's risk (I8 and 22) change. Moreover, it changes the level of the conventional leverage ratio (quantity of firms indebtedness considered as normal $\left(l e v_{c}\right)$ ).

$$
\begin{aligned}
& L R=-\gamma_{4}^{\prime}+a_{1}\left(l e v_{-1}-\gamma^{\prime}{ }_{7} l e v_{c}\right)-b_{1} V_{C}+c_{1} i_{c b}, \\
& l r=-\gamma_{5}^{\prime}+a_{2}\left(l e v_{-1}-\gamma_{8}^{\prime} l e v_{c}\right)-b_{2} V_{C}, \\
& \gamma_{4}^{\prime}=\gamma_{4} a_{4} B C I \text { and } \gamma_{7}^{\prime}=\gamma_{7} a_{7} B C I,
\end{aligned}
$$




$$
\gamma_{5}^{\prime}=\gamma_{5} a_{5} B C I \text { and } \gamma_{8}^{\prime}=\gamma_{8} a_{8} B C I
$$

Generalised crisis in the state of confidence (banks, firms, households): $B+F+H$ I put together these three processes for a generalised analysis of the state of confidence of the private sectors. In the experiments, the respective importance of the different economic sectors on the economic situation is not relevant. The changes in the state of confidence of banks and firms involve supply shocks. In contrast, the changes in the state of confidence of household involve shock of demand.

\section{Experiments with the state of confidence of French private sectors}

Following the approaches of Minsky and Keynes, confidence is an important channel of transmission of the US financial crisis to the French real economy. In our experiments with the model, the drop in the state of confidence of firms at the beginning of 2008 largely explains the decline of the growth rate of the economy (GrY-F) because it depressed effective demand, i.e. the desired growth rate of accumulation of capital (Figure 3). But, banks have also a little responsibility (GrY-B), because financing conditions deteriorated. The crisis is deeper after August 2008. The rate of utilisation of productive capacity falls. However, it is the state of confidence of firms (effective demand) that is the driving force in the economy, as Keynes (1936: chapter XII) explained in the General Theory $(\mathrm{GrY}-\mathrm{B}+\mathrm{F}+\mathrm{H})$.

Figure 3: State of confidence in France: Effects on the growth rate of the economy

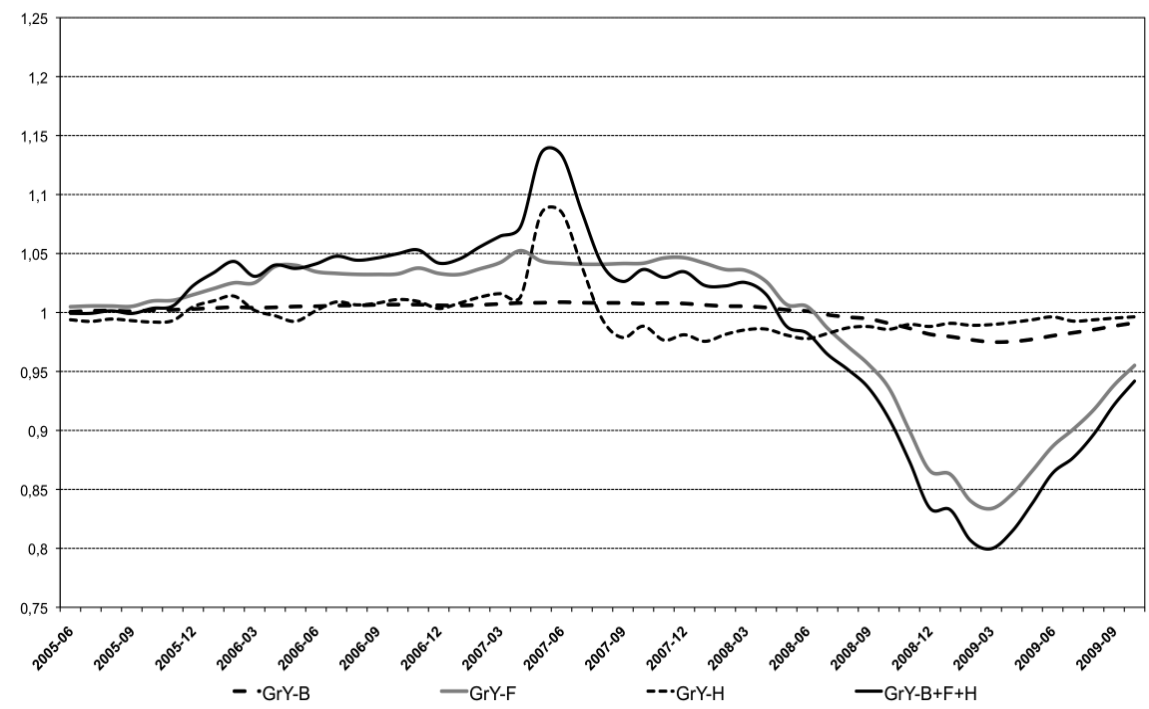


Strangely consumer confidence rose sharply in the second quarter of 2007 (GrY-H). This wave of optimism is due to the election of President N. Sarkozy. But it was short-lived and had no lasting effect on the economy in the real world. This confirms that household expectations have little influence on production.

If we compare the observed rate of real growth (growth rate regarding to the same quarter of the previous year, seasonally adjusted, source: Trim-year GYSA, OECD) and our simulation, we note a strong convergence but with a little delay. As we would expect, the expectations (state of confidence) seem to precede and to explain changes in the observed economic growth of France. Thus, introducing only the recorded confidence of French economic agents, the model perfectly simulates the reality of the French production crisis (Figure 4).

Figure 4: Real growth rate of French GDP (black curve, 2005-2009) and estimated growth rate of GDP generated by the model $(G r Y-B+F+H$, grey curve)

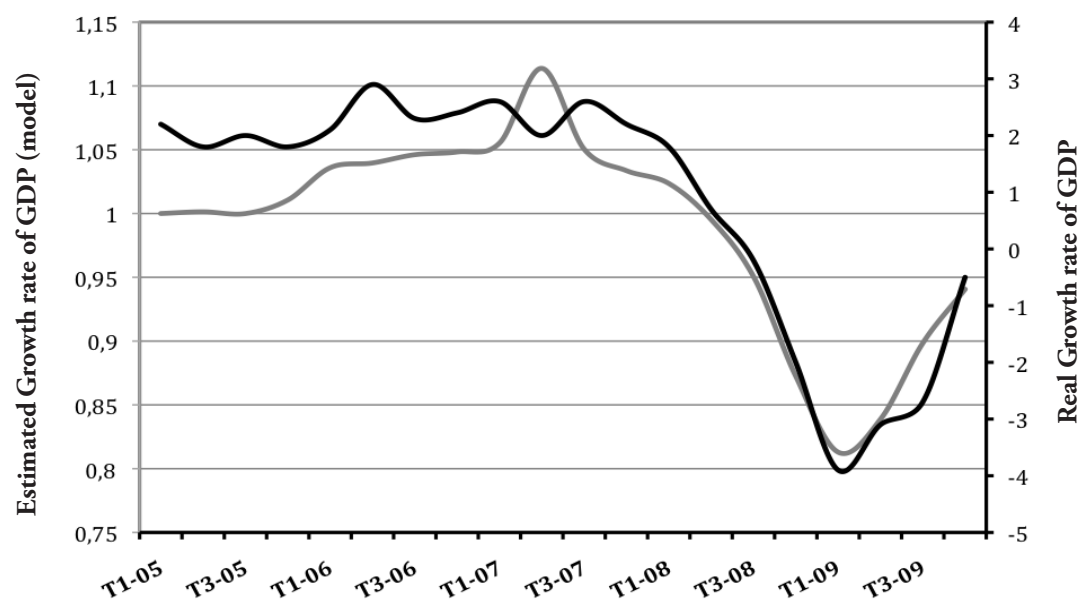

Source: OECD and author's calculations

The effects on the self-financing of firms are interesting (Figure 5). With the higher borrower's and lender's risks, firms and banks reduce external financing, but the strong fall of the demand of financing avoids a credit crunch. The self-financing of firms increases, because they refuse to go into debt and this corresponds to the supply shock. The leverage ratio of firms increases with the shock of demand (households), but strongly decreases with rising borrower's risk. Firms reduce seriously their indebtedness and it positively impacts the lender's risk of banks. On the contrary, the lost confidence of households involves a shock of demand and little decrease in self-financing of firms. 
Figure 5: State of confidence in France:

Effects on the ratio of self-financing of firms (SelF)

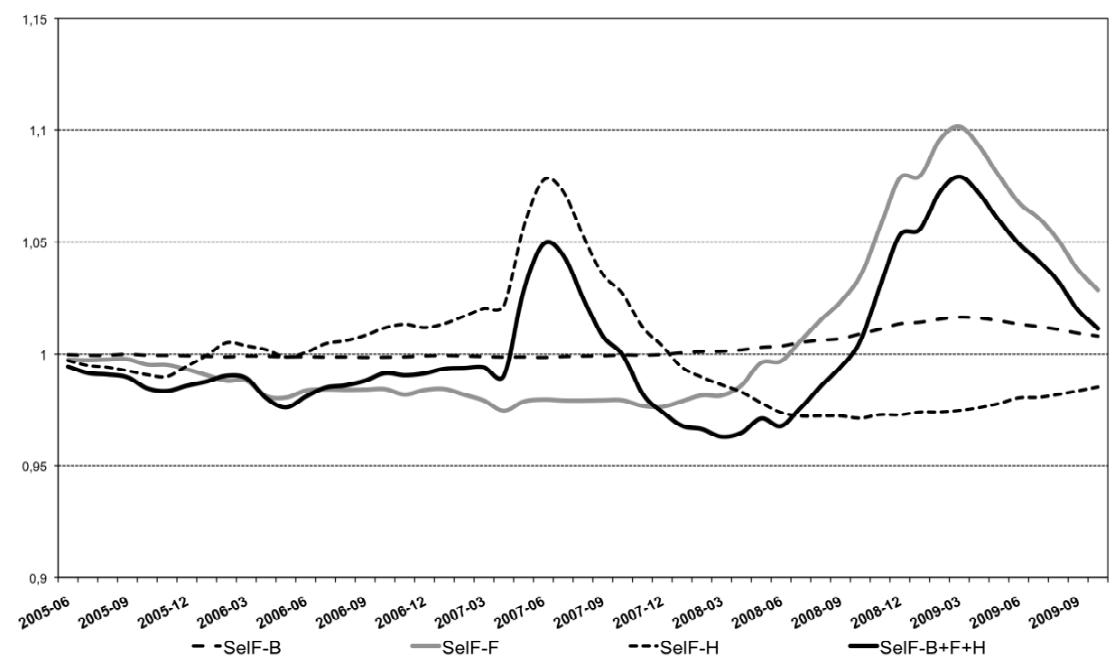

With the expectations of banks, lender's risk increases. But the global effect of the reduction of firms' indebtedness is a lower lender's risk and we observe no important rationing on firms (Figure 6). The fall of collateral value, the supposed lower solvency of firms and the

Figure 6: State of confidence in France:

Effects on the rationing of finance from banks $(R F)$

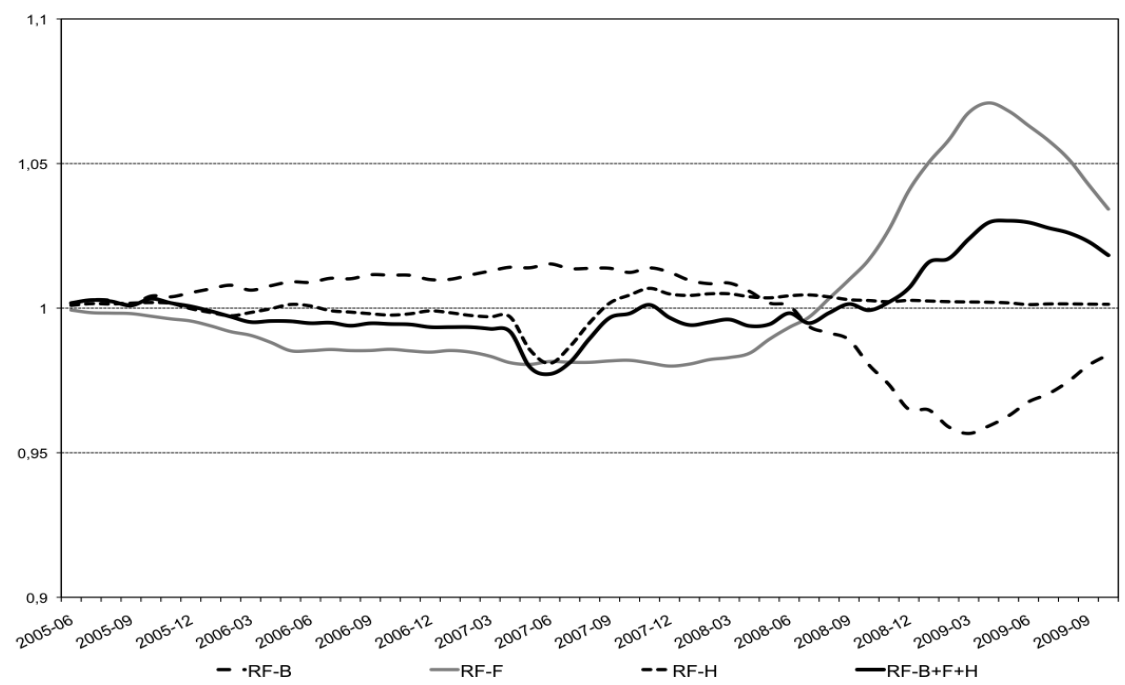


new stricter convention of firm indebtedness explain the rise of the lender's risk from the banks' point of view.

With the policy mix, the higher government deficit allows an increase of the cash flow of firms. Their self-financing increases. Government indebtedness substitutes for that of firms. The negative impact of the crisis in the banking sector on the government deficit is evident. A fall in the state of confidence in the private sector and the crisis suggest that the government `becomes` optimistic and supports effective demand with an increasing fiscal deficit in 2008 (Figure 7). This is the case in France with a maximum of 8.5 percent of GDP.

Figure 7: State of confidence in France: Effects on the fiscal deficit (DG)

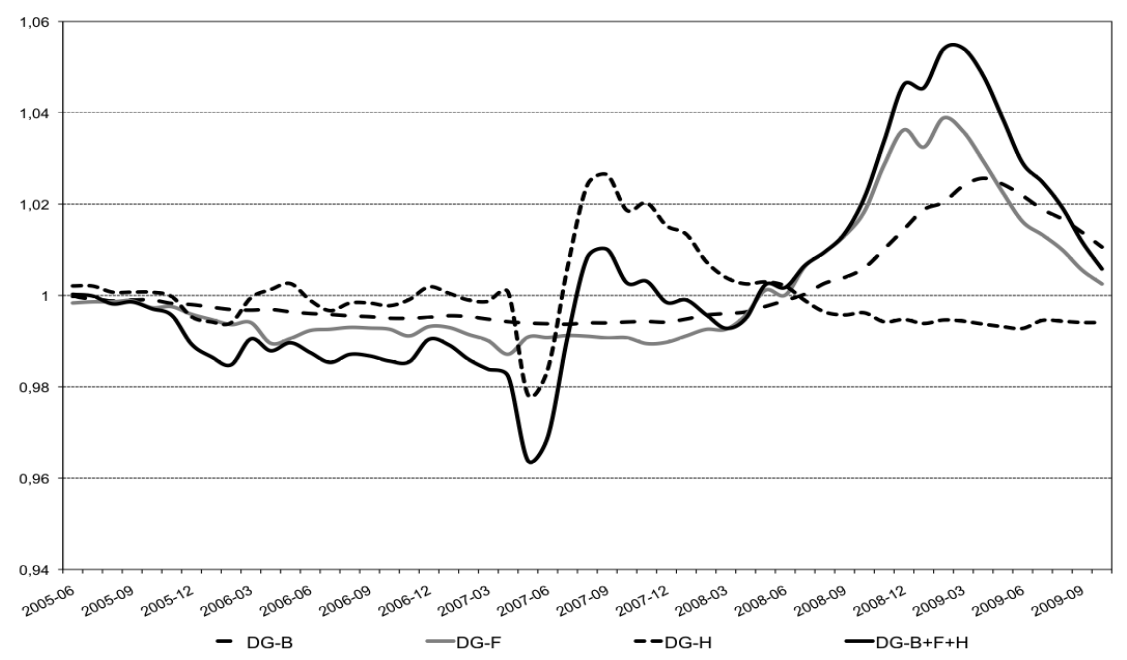

The consequence is weak finance rationing of the investment in firms by private banks: $\varphi<\varphi^{d}$, during the end of the boom. But during the crisis, the firms reduce deeply their demand of financing and consequently, there is no credit crunch, even if there is a significant fall in the profit of banks. A credit crunch is not a satisfactory explanation for understanding the transmission channel of this financial crisis to the real world. During the crisis, the structure of the balance sheet of private banks clearly changes. It is sure that our model overestimates the size of equities. In a financialised economy, the firms finance more the financial market than the financial market finances the firms.

We see disinflation after May 2007 and the beginning of deflation at the end of 2008 (Figure 8). With the deep crisis, monetary policy tries to avoid deflation, and then the flexible Taylor rule focuses on unemployment. The key interest rate goes down quickly to stop the fall of prices and of asset prices. The influence of the output gap on the key interest rate is in the same direction but is lower than that of inflation, even with our flexible Taylor rule. 
Figure 8: State of confidence in France: Effects on the rate of inflation (INF)

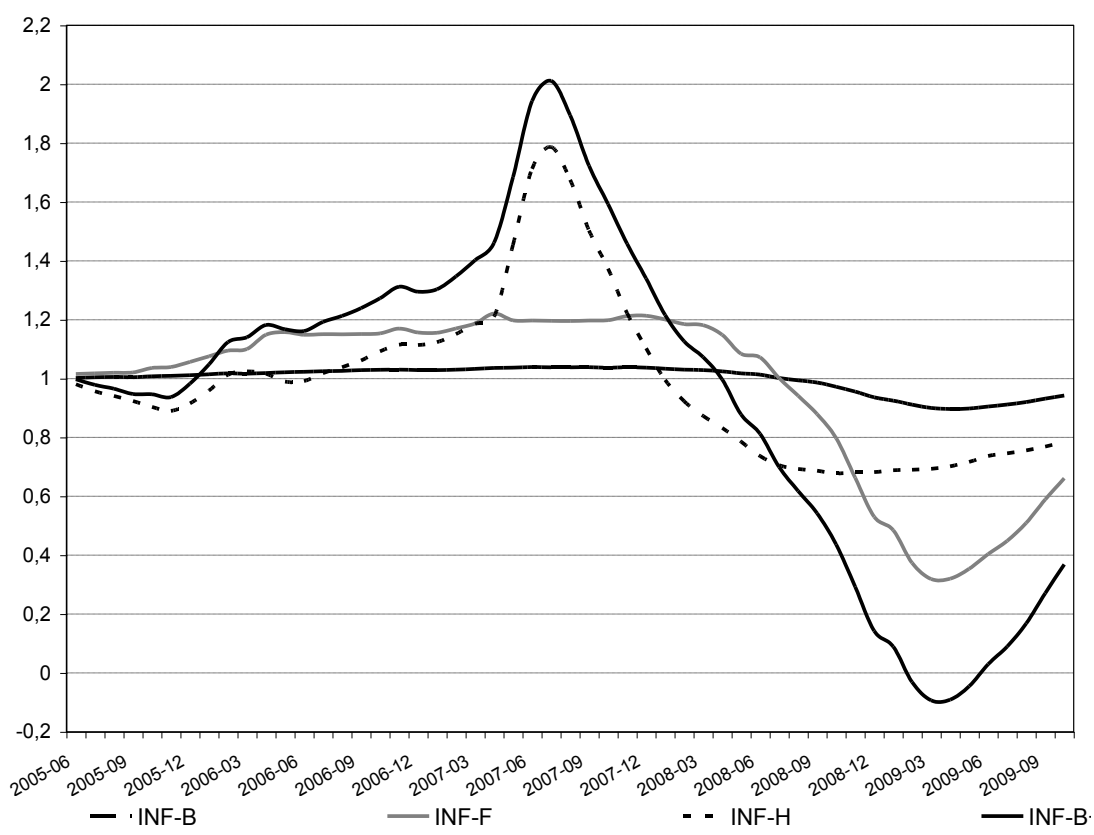

Contrary to IS-LM, New-Keynesians or usual post-Keynesian SFC models, the curve of interest rates is not exogenous. The spread between the short-term and the long-term interest rate is not constant. First, the model shows the same evolution as the stylised facts of the last crisis: a rise of this spread, which corresponds to higher lender's risk, at the time of the key rate decreasing at the central bank. Second, the central bank lowered its key interest rate faster than inflation, particularly to boost the prices of capital assets. We find that the real long-term interest rate decreased more slowly than other rates, which reduces the effect of expansionary monetary policy.

\section{Conclusions}

To better understand the last financial crisis and its spread to the real world, I have tried to take into account the behaviour of private banks, the financial risks of firms and banks, and the psychological variables with the state of confidence of private sectors. In order to do so, Keynes and Minsky give an adequate framework. I argue that confidence is a fundamental transmission channel of a financial crisis to the real world in a global economy. I showed that expectations play a key role in the transmission of the financial sector crisis to the real sector and could well be self-fulfilling. Firms' expectations are the most important, because they largely explain the movement of reffective demand،. 


\section{Appendix I: Glossary of variables}

$\begin{array}{ll}Y & \text { National income } \\ Y_{f c} & \text { Output of full capacity } \\ g r_{y} & \text { Growth rate in the national income } \\ \Pi & \text { Inflation } \\ \Pi^{*} & \text { Inflation target } \\ N & \text { Employment } \\ N_{f e} & \text { Full employment } \\ O G & \text { Output gap } \\ O G_{R} & \text { Ratio of output gap } \\ U n & \text { Unemployment } \\ r_{u n} & \text { Rate of unemployment } \\ L & \text { Loans (variable long-term rate) } \\ C P & \text { Commercial paper } \\ B & \text { Treasury bills } \\ E & \text { Equities } \\ e & \text { Number of equities } \\ p_{e} & \text { Price of equities } \\ O F & \text { Bonds (fixed rate) } \\ o f & \text { Number of bonds } \\ p_{o f} & \text { Price of fixed rate bonds } \\ L F & \text { Loss function of the society } \\ & \end{array}$

$C G$ Capital gains of banks (Capital losses of firms)

$\mathrm{CGe}$ Capital gains on equities

$C G_{e}^{a} \quad$ Expected capital gains on equities

CGof Capital gains on bonds

$C G_{o f}^{a} \quad$ Expected capital gains on bonds

icp Interest rate on commercial paper

$i_{d} \quad$ Interest rate on deposits

$i_{l} \quad$ Interest rate on loans

$i_{b} \quad$ Interest rate on treasury bills

FCI Financial Condition Index

$L R \quad$ Lender's risk

lr Lender's risk for long-term interest rate

$\gamma_{4}, \gamma_{5} \quad$ State of confidence of banks

$r_{o f}^{a} \quad$ Expected yield of bonds

$r_{e}^{a} \quad$ Expected return on equities

Pd Expected distributed profits

lev Leverage ratio

$V C \quad$ Variation of the value of collateral

\section{Firms}

\section{Central Bank}

$P_{c b} \quad$ Central bank profits

$R E F \quad$ Reserve requirements (CB refunds)

$H \quad$ High-powered money

$i_{c b} \quad$ Central bank key interest rate

$i^{*} \quad$ Neutral interest rate

$\alpha_{4} \quad$ Flexible coefficient on output gap

$\alpha_{6} \quad$ Flexible coefficient on inflation gap

\section{Commercial Banks}

$P_{b} \quad$ Banks profits

$V_{b} \quad$ Net wealth of banks

I Net investment

$I_{D} \quad$ Investment demand

$W \quad$ Wages

$K \quad$ Stock of capital

$V_{f} \quad$ Net wealth of firms

$u \quad$ Capacity utilization rate

$g r_{k} \quad$ Growth rate in the stock of capital

$g r_{k D} \quad$ Desired growth rate in the stock of capital

$\Delta F \quad$ Net finance

$\varphi \quad$ Gross finance

$\varphi^{d} \quad$ Desired gross investment

IF Internal funds 
amort Amortization (debt redemption)

$P \quad$ Firms profits

$P^{d} \quad$ Distributed profits

$P^{u} \quad$ Undistributed profits

$r_{c f} \quad$ Borrower's risk (ratio of cash flow)

$\gamma_{0} \quad$ State of confidence of firms

\section{Government}

$G \quad$ Government expenditure

$D G \quad$ Government deficit

$g_{d g} \quad$ Constant ratio of government deficit

$P_{c b} \quad$ Central bank profits

$T \quad$ Taxes

\section{Households}

C Consumption

D Bank deposits

$Y_{w}^{a} \quad$ Expected disposable income of workers

$Y_{v}^{a} \quad$ Expected disposable financial income

$Y_{w} \quad$ Disposable income of workers

$Y_{v} \quad$ Disposable financial income

$Y_{h} \quad$ Disposable income of household

$\gamma_{6} \quad$ Index of state of confidence of households 


\section{Appendix 2: The complete model}

(I) $\quad Y=C+I+G$

(2) $\quad g r_{y}=\Delta Y / Y_{-1}$

(3) $T=\tau W_{-1}$, where $\tau$ is a constant

(4) $B=B_{-1}+D G$

(5) $\quad i_{b}=i_{l}$

(6) $\quad G=G_{-1}\left(1+g r_{y-1}\right)$

(7-i) $\quad D G \equiv G+i_{b-1} B_{-1}-T-P_{c b}$

(8) $\quad K=K_{-1}+I$

(9-iii) $I \equiv \varphi+I F$

(Io) $\quad I F=P^{u}-$ amort

(II) $\quad$ amort $=a_{l} L_{-1}+a_{o f} o f_{-1}+a_{C P} C P_{-1}$

(I2) $\quad I_{D}=g r_{k D} K-1$

(I3) $\varphi^{d}=I^{d}-I F$

(I4) $\quad g r_{k D}=\gamma_{0}+\gamma_{1} r_{c f-1}+\gamma_{2} u_{-1}-\gamma_{3} F C I_{-1}$, where $\gamma_{i}$ are constants

(I5) $\quad r_{c f}=P^{u} / K_{-1}$

(I6) $u=Y / Y_{f_{c}}$

(I7) $\quad Y_{f c}=K_{-1} \sigma$, where $\sigma$ is a constant

(I8) $\quad F C I=\mu_{1} i_{l} L / K+\mu_{2} i_{c b} C P / K-\mu_{3} E / Y$, where $\mu_{i}$ are constants

(I9) $\quad O G_{R}=\left(Y_{f c}-Y\right) / Y_{f c}$

(20) $W=Y /(1+\rho)$, where $\rho$ is a constant

(2I-ii) $\quad P \equiv Y-W-i_{l-1} L_{-1}-i_{C P-1} C P_{-1}-i_{o f} o f_{-1}$

(22) $P^{d}=\left(1-s_{f}\right) P_{-1}$, where $s_{f}$ is a constant

(23-ix) $\quad P^{u} \equiv P-P^{d}$

(24) $e=e_{-1}\left(1+g r_{y-1}\right)$, where $g r_{e}$ is a constant
National income

Growth rate (of national income)

Taxes

Treasury bills

Interest rate on treasury bills

Government expenditure

Government deficit

Stock of capital

Net investment

Self financing

Internal funds

Demand of investment

Desired gross investment

Desired growth in the stock of capital

Borrower's risk (ratio of cash flow)

Capacity utilization rate

Output of full capacity

Financial Condition Index

Output gap ratio

Wages

Firms profits

Distributed profits

Non distributed profits

Number of equities 
(25) $C=\left(\alpha_{1}^{\prime} \gamma_{6} Y_{w}{ }^{a}\right)+\left(\alpha_{2} Y_{v}^{a}\right)+\left(\alpha_{3}^{\prime} D_{-1}\right)$,

Consumption where $\alpha_{i}$ are constants

(26) $Y_{w}^{a}=Y_{w-1}+\theta_{h}\left(Y_{w-1}-Y_{w-1}^{a}\right)$, where $\theta_{h}$ is a constant

(27) $Y_{v}^{a}=Y_{v-1}+\theta_{h}\left(Y_{v-1}-Y_{v-1}^{a}\right)$, where $\theta_{h}$ is a constant

Expected disposable income of workers

Expected disposable financial income

(28) $\quad Y_{w}=W-T$

Disposable wage income

(29) $\quad Y_{v}=i_{d-1} D_{-1}$

Disposable financial income

(30) $Y_{h}=Y_{w}+Y_{v}$

Disposable income of workers

(3I-iv) $\quad D \equiv D_{-1}+Y_{h}-C$

Bank deposits

(32) $\varphi=\varphi^{d}(1-L R)$

Gross finance

(33) $\Delta F=\varphi-$ amort $+C G$

Net finance

(34) $C G=C G_{e}+C G_{\text {of }}$

Capital gains of banks (Capital losses of firms)

(35) $L R=\gamma_{4}+a_{1}\left(l e v_{-1}-l e v_{c}\right)-b_{1} V_{C}+c_{1} i_{c b}$,

Lender's risk where $\gamma_{4}, a_{1}, b_{1}, l e v_{c}$ and $c_{1}$ are constants

(36) $l e v=(C P+O F+L) / K$

Leverage ratio

(37) $\quad V_{C}=E / E_{-1}$

Value of the collateral

(38) $\quad O F=\left(\lambda_{10}+\lambda_{11} r_{o f}^{a}-\lambda_{12} r_{e}^{a}-\lambda_{13} i_{l}-\lambda_{14} i_{C P}\right) F$

Bonds (fixed rate)

(39) $E=\left(\lambda_{20}-\lambda_{21} r_{\text {of }}^{a}+\lambda_{22} r_{e}^{a}-\lambda_{23} i_{l}-\lambda_{24} i_{C P}\right) F$

Equities

(40) $\quad L=\left(\lambda_{30}-\lambda_{31} r_{o f}^{a}+\lambda_{32} r_{e}^{a}-\lambda_{33} i_{l}-\lambda_{34} i_{C P}\right) F$

Loans (variable long-term rate)

(4I) $\quad C P=F-O F-E-L$

Commercial paper

(42) $\quad r_{\text {of }}^{a}=i_{\text {of }}+C G_{\text {of }}^{a} / O F_{-1}$,

Expected yield of bonds where $i_{\text {of }}$ is a constant

(43) $\quad C G_{o f}^{a}=C G_{o f-1}+\theta_{b}\left(C G_{o f-1}-C G_{o f-1}^{a}\right)$

Expected capital gains on bonds

(44) $\quad C G_{o f}=\Delta p_{o f} o f_{-1}$

Capital gains on bonds

(45) of $=O F / p_{\text {of }}$

Number of bonds

(46) $\quad p_{o f}=p_{o f-1}\left(1+i_{o f}\right) /\left(1+i_{l}\right)$

Price of bonds (fixed interest rate)

(47) $\quad r_{e}^{a}=\left(P^{d a}+C G_{e}^{a}\right) / E_{-1}$

Expected return on equities 
(48) $\quad P^{d a}=P_{-1}^{d}+\theta_{b}\left(P_{-1}^{d}-P_{-1}^{d a}\right)$

Expected distributed profits

(49) $\quad C G_{e}^{a}=C G_{e-1}+\theta_{b}\left(C G_{e-1}-C G_{e-1}^{a}\right)$

Expected capital gains on equities

(50) $\quad C G e=\Delta p_{e} e_{-1}$

Capital gains on equities

(5I) $\quad p_{e}=E / e$

Price of equities

(52) $i_{l}=i_{c b}+l r+\chi_{1}$, where $\chi_{1}$ is a constant

Interest rate on loans

(53) $\quad l r=-\gamma_{5}+a_{2}\left(l e v_{-1}-l e v_{c}\right)-b_{2} V_{C}$

Lender's risk for long-term interest rate with $\gamma_{5}, a_{2}$ and $b_{2}$, Lev $v_{c}$ constant $=$ convention on leverage ratio

(54) $\quad i_{c p}=i_{c b}+\chi_{2}$

With $\chi_{2}$ : constant $\chi_{1}>\chi_{2}>\chi_{3}$, Interest rate on commercial paper

(55) $i_{d}=i_{c b}-\chi_{3}$

Interest rate on deposits

(56-v) $\quad P_{b} \equiv i_{b-1} B_{-1}+i_{l-1} L_{-1}+i_{c p-1} C P_{-1}+i_{o f} o f_{-1}+P^{d}-i_{d-1} D_{-1}-i_{c b-1} R E F_{-1}$ Banks profits

(57) $H=\eta D$

High powered money

(bank reserves)

(58-vii) $\quad P_{c b} \equiv i_{c b-1} R E F_{-1}$

Central bank profits

(59) $i_{c b}=i^{*}+\Pi-\alpha_{4} O G_{R}+\alpha_{6}\left(\Pi-\Pi^{*}\right)$

Central bank key interest rate (Taylor rule)

$$
\alpha_{4}=\alpha_{4(-1)}+\left(a l_{4}\left(O G_{R}-O G_{R(-1)}\right)\right)
$$

Flexibility on output gap in the Taylor rule

$$
\alpha_{6}=\alpha_{6(-1)}+\left(a l_{6}\left(\Pi-\Pi_{(-1)}\right)\right)
$$

Flexibility on inflation in the Taylor rule

(62-vi) $\quad R E F \equiv R E F_{-1}+\Delta H+\Delta B+\Delta F-C G-P_{b}-\Delta D \quad$ Reserve requirements (CB refunds)

$$
\Pi=\Pi^{*}+d_{1}\left(O G_{R \operatorname{mini}}-O G_{R}\right)+d_{2}\left(O G_{R \operatorname{maxi}}-O G_{R}\right) \quad \text { Inflation (NKPC) }
$$

Missing equation ${ }^{4}$ :

(64-viii) $R E F=H$

4 We have defined the 25 variables of the transactions matrix introducing 38 new variables and we now have the same number of equations $\left(6_{3}\right)$ and unknowns. Furthermore, we have managed to use the $M+N-1=8$ accounting identities (Latin numbering) issued from the transcription of the transactions matrix. 


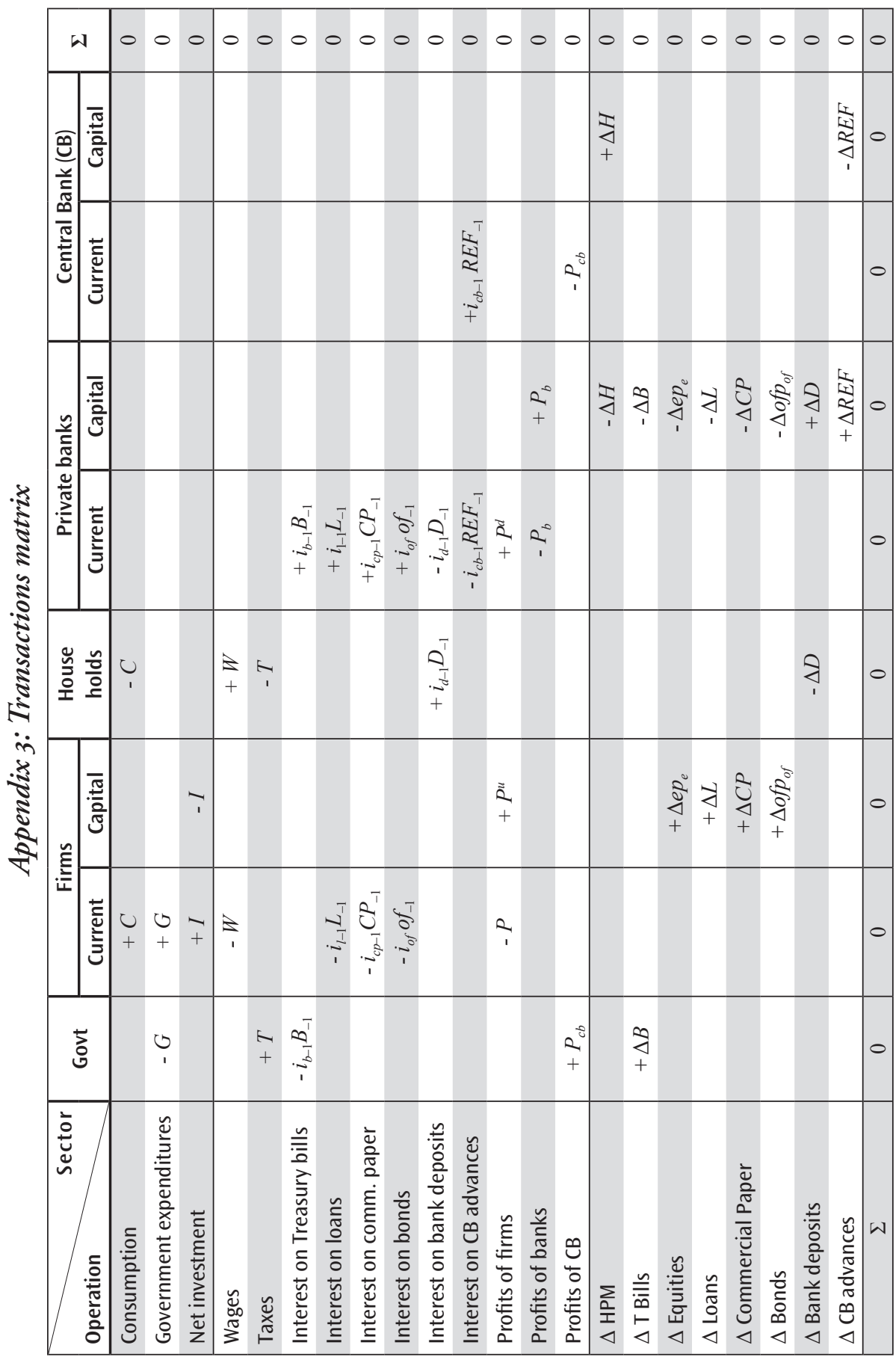




\section{Appendix 4: Balance sheet matrix}

\begin{tabular}{|c|c|c|c|c|c|c|}
\hline Assets Sector & Government & Firms & Households & $\begin{array}{c}\text { Private } \\
\text { banks }\end{array}$ & $\begin{array}{c}\text { Central } \\
\text { Bank }\end{array}$ & $\Sigma$ \\
\hline Capital & & $+K$ & & & & $+K$ \\
\hline $\begin{array}{l}\text { HPM } \\
\text { High powered money }\end{array}$ & & & & $+H$ & $-H$ & 0 \\
\hline Treasury Bills & $-B$ & & & $+B$ & & 0 \\
\hline Equities & & $-e p_{e}$ & & $+e p_{e}$ & & 0 \\
\hline Loans & & $-L$ & & $+L$ & & 0 \\
\hline Commercial paper & & $-C P$ & & $+C P$ & & 0 \\
\hline Bonds (fixed-yield) & & $-o f p_{o f}$ & & $+o f p_{o f}$ & & 0 \\
\hline Bank deposits & & & $+D$ & $-D$ & & 0 \\
\hline CB advances & & & & $-R E F$ & $+R E F$ & 0 \\
\hline Net wealth & $-B$ & $+V_{f}$ & $+D$ & $+V_{b}$ & 0 & $+K$ \\
\hline
\end{tabular}

\section{References}

Bernanke, B., Gertler, M., Gilchrist, S. (1999): The financial accelerator in a quantitative business cycle framework, in: Handbook of Macroeconomics, chapter 2I, Vol. I, Amsterdam: NorthHolland, I34I-93.

Creel, J., Capoen, F. (2007): Efficiency of stability-oriented institutions: The European case, OFCE, Working Paper, No. 2007-06, February.

Davidson, P. (2007): John Maynard Keynes, New York: Palgrave Macmillan.

Davis, M., Palumbo, M. (200I): A primer on the economics and time series econometrics of wealth effects, fed finance and economics discussion series, No. 200I-09.

Dos Santos, C., Zezza, G. (2004): A post-Keynesian stock-flow consistent macroeconomic growth model: Preliminary results, The Levy Economics Institute, Working Paper, No. 402, February.

Eichner, A.S. (1976): The Megacorp and Oligopoly, Cambridge, UK: Cambridge University Press. Godley, W., Lavoie, M. (2007): Monetary Economics: An Integrated Approach to Credit, Money, Income, Production and Wealth, London: Palgrave Macmillan.

Kalecki, M. (1937): The principle of increasing risk, in: Economica, 4(16), 440-447.

Keynes, J.M. (1936): The General Theory of Employment, Interest and Money, London: Macmillan. Keynes, J.M. (1973 [1936]): The General Theory, The collected writings of J.M. Keynes, vol VII, London: Macmillan.

Lavoie, M., Godley W. (200I): Kaleckian growth models in a stock and flow monetary framework: A Kaldorian View, in: Journal of Post Keynesian Economics, 24(2), 277-3II. 
Le Heron, E. (2006): Greenspan: The confidence strategy, in: Revista de Economia Political Brazilian Journal of Political Economy, 26(4)-104, 502-517.

Le Heron, E. (2007a): The dynamic analysis of monetary policy shock on banking behavior, in: McCombie, J., Rodriguez, C. (eds.), Issues in Finance and Monetary Policy, London: Palgrave-Macmillan, 79-99.

Le Heron, E. (2007b): The new governance in monetary policy: A critical appraisal of the fed and the ECB, in: Arestis, P., Hein, E., Le Héron, E. (eds.), Aspects of Modern Monetary and Macroeconomic Policies, London: Palgrave-Macmillan, Chapter 9, I46-7I.

Le Heron, E., Mouakil, T. (2008): A Post Keynesian stock-flow consistent model for the dynamic analysis of monetary policy shock on banking behavior, in: Metroeconomica, 59(3), 405-40.

Le Heron, E. (2008): Fiscal and monetary policies in a Keynesian stock-flow consistent model, in: Creel, J., Sawyer, M. (eds.), Current Thinking on Fiscal Policy, London: PalgraveMacmillan, Chapter 8, I45-75.

Le Heron, E. (2009): Monetary and fiscal policies in a post Keynesian stock-flow consistent model, in: Wray, R., Forstater, M. (eds.), Keynes and Macroeconomics after 70 Years: Critical Assessments of the General Theory, Aldershot: Edward Elgar, Chapter I8, 468-506.

Leijonhufvud, A. ([1973] I98I): Effective Demand Failures, in: Swedish Journal of Economics, 75, 27-48. Reprinted in: Leijonhufvud, A. (1981), Information and Coordination. Essays in Macroeconomic Theory, New York: Oxford University Press.

Minsky, H. (1975): John Maynard Keynes, New York: Columbia University Press.

Mouakil, T. (2006): Instabilité financière et méthode stocks-flux: Analyse critique de l'hypothèse de Minsky, PhD, University Montesquieu Bordeaux 4, November.

Rotemberg, J., Woodford, M. (1997): An optimisation-based econometric framework for the evaluation of monetary policy, in: NBER Macroeconomics Annual, 297-346.

Taylor, J. (1979): Staggered contracts in a macro model, in: American Economic Review, 69, IO8-I3.

Taylor J. (1993): Discretion versus policy rules in practice, Carnegie-Rochester Conference Series on Public Policy, No. 39, 195-2I4.

Tobin, J. (1958): Liquidity preference as behavior toward risk, in: Review of Economic Studies, $25(2), 65-86$.

Tobin, J. (1969): A general equilibrium approach to monetary theory, in: Journal of Money, Credit, and Banking, I, I5-29.

Van den Heuvel, S.J. (2002): The bank capital channel of monetary policy, The Wharton School, University of Pennsylvania, mimeo.

Woodford, M. (2003): Interest and Prices: Foundations of a Theory of Monetary Policy, Princeton: Princeton University Press. 
